\title{
Paleomagnetism of Middle-Late Triassic plutons in southern Maine
}

\author{
FANG WU and ROB VAN DER VOO \\ Department of Geological Sciences, University of Michigan, Ann Arbor, MI 48109 (U.S.A.)
}

(Received December 16, 1987; accepted March 28, 1988)

\begin{abstract}
Fang Wu and Van der Voo, R., 1988. Paleomagnetism of Middle-Late Triassic plutons in southern Maine. Tectonophysics, 156: 51-58.

A paleomagnetic study of two small syenitic to alkali-granitic plutons, Abbott and $A$ gamenticus (southern Maine), yields paleopoles at $48^{\circ} \mathrm{N}, 92^{\circ} \mathrm{E}$, and $48^{\circ} \mathrm{N}, 99^{\circ} \mathrm{E}$, with $\mathrm{K}-\mathrm{Ar}$ ages of $221 \pm 8$ and $228 \pm 5 \mathrm{Ma}$, respectively. A third pluton, the Litchfield, was much more weathered and did not contain stable magnetizations. Dual-polarity magnetizations, a dike contact test, and excellent statistical parameters obtained after detailed thermal and alternating field demagnetization support our claim that the magnetizations and paleopoles are representative of the Middle to Late Triassic paleomagnetic field. However, the two paleopoles fall about $10^{\circ}$ to the southwest of previously published Triassic apparent polar wander path segments for cratonic North America. Unless this small deviation can be ascribed to post-Triassic tilt of the plutons, this requires a modification of the polar wander path. To bring the poles into agreement, a tilt correction of some $15-20^{\circ}$ needs to be applied about a strike which is perpendicular to the area's geologic trends and the Main coast line, which appears to be highly unlikely given the stabilized tectonic setting of this area in post-Triassic time. A small but significant revision of the North American cratonic apparent polar wander path may therefore be suggested by these results, but this needs further corroboration. The more southerly paleolatitudes indicated by these Triassic results for North America would imply lesser displacements than previously proposed on the basis of Triassic paleomagnetism for exotic terranes in the western Cordillera.
\end{abstract}

\section{Introduction}

The Triassic apparent polar wander path (APWP) segment of cratonic North America appears to be well constrained, but especially for Middle and Late Triassic times it is based on only a few imprecisely defined paleopoles. Comparisons between the cratonic APWP and Triassic poles from displaced terranes in the western Cordillera are therefore subject to uncertainties of at least $10^{\circ}$.

Gordon et al. (1984) and May and Butler (1986) have recently updated the North American APWP, resulting in a significant difference with the previous path published by Irving and Irving (1982) for
Late Triassic to Late Jurassic time (about 220 to $150 \mathrm{Ma}$ ). This difference is the result of the addition of new results, as well as the rejection by the former authors of paleopoles no longer considered as reliable. The revision, as noted by May and Butler (1986), implies more southerly Jurassic paleolatitudes for North America than previously thought, and lesser displacements for terranes such as Stikinia and Wrangellia (Monger and Irving, 1980; Hillhouse and Grommé, 1984).

Here we report paleomagnetic results from small Triassic plutons in Maine. The study was undertaken to add well-dated paleopoles to the data base and to refine the APWP for the period preceding that studied by May and Butler. Previously 
existing paleopoles for the Middle and Late Triassic are primarily based on studies of sedimentary rocks in which the age of the magnetization acquisition is subject to uncertainties. For welldated igneous rocks, reflected light petrography and rock magnetic experiments can usually reduce such age uncertainties. Although structural tilt cannot be determined directly for plutonic rocks, it was our hope that no tilt correction would be necessary, in view of the tectonic stability of the area in post-Paleozoic time.

\section{Geology and sampling}

Locations of the three sampled plutons, Litchfield, Abbott and Agamenticus, are given in Fig. 1 , with sampling sites indicated in the insets. All three plutons are relatively small, of syenitic to alkali-granitic composition (Hussey, 1962; Barker, 1965; McHone and Butler, 1984), and hosted by

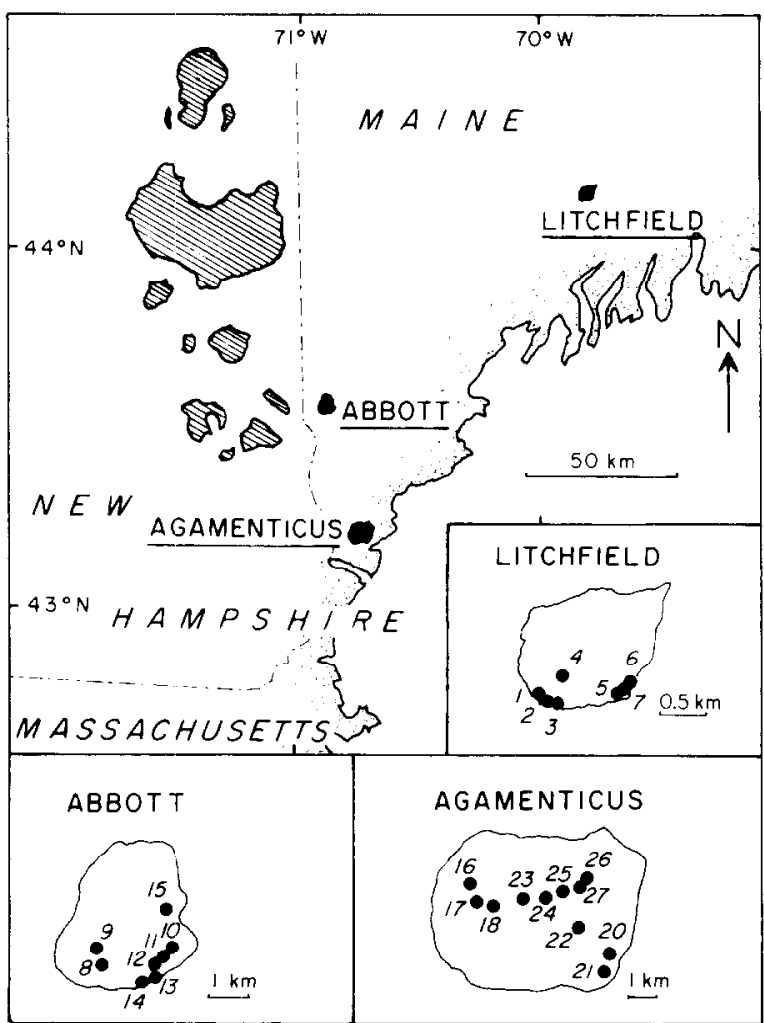

Fig. 1. Regional map of the southern Maine area and detailed inset maps of the Middle to Late Triassic plutons, with sampling sites indicated. The grey shading represents the White Mountain plutonic complex.
TABLE 1

Summary of Paleomagnetic Means

\begin{tabular}{lcrrr}
\hline Site & $n / N$ & Decl./Incl. & \multicolumn{1}{l}{$k$} & $\alpha_{95}$ \\
\hline Abbott Pluton & & & & \\
8 & $5 / 7$ & $191.6 /-4.6$ & 97 & 7.8 \\
9 & $3 / 6$ & $197.8 /-6.1$ & 46 & 18.3 \\
11 & $4 / 6$ & $190.8 /-1.5$ & 58 & 12.2 \\
12 & $4 / 5$ & $192.8 /-6.1$ & 86 & 10.0 \\
13 & $4 / 5$ & $187.0 /-6.0$ & 164 & 7.2 \\
14 & $3 / 7$ & $192.3 /-8.7$ & 85 & 13.5 \\
15 & $2 / 8$ & $184.0 /-7.5$ & - & - \\
Mean * & $7 / 8$ & $191.1 /-6.0$ & 242 & 3.9 \\
paleopole at $48.3^{\circ} \mathrm{N}, 92.3^{\circ} \mathrm{E}$ & & \\
Mean ** & $4 / 8$ & $190.6 /-4.6$ & 607 & 3.7 \\
paleopole at $47.7^{\circ} \mathrm{N}, 93.4^{\circ} \mathrm{E}$ &
\end{tabular}

\begin{tabular}{|c|c|c|c|c|}
\hline \multicolumn{5}{|c|}{ Agamenticus Pluton } \\
\hline 17 & $2 / 3$ & $12.5 /+8.0$ & - & - \\
\hline 18 & $3 / 3$ & $183.7 /-4.0$ & 198 & 8.8 \\
\hline 20 & $3 / 5$ & $5.0 /+4.0$ & 174 & 9.4 \\
\hline 22 & $4 / 4$ & $183.4 /+1.3$ & 91 & 9.7 \\
\hline 23 & $3 / 3$ & $189.1 /-5.7$ & 42 & 19.2 \\
\hline 24 & $4 / 4$ & $192.8 /-4.3$ & 65 & 11.5 \\
\hline 25 & $4 / 5$ & $5.9 /+7.5$ & 93 & 9.6 \\
\hline 26 & $7 / 7$ & $182.2 /-3.9$ & 260 & 3.7 \\
\hline 27 & $6 / 6$ & $188.8 /-0.8$ & 41 & 10.6 \\
\hline \multicolumn{5}{|c|}{ paleopole at $48.4^{\circ} \mathrm{N}, 98.6^{\circ} \mathrm{E}$} \\
\hline \multicolumn{5}{|c|}{ paleopole at $47.6^{\circ} \mathrm{N}, 99.4^{\circ} \mathrm{E}$} \\
\hline $\begin{array}{l}\text { R-mcan } \\
\text { paleopc }\end{array}$ & \multicolumn{3}{|c|}{ paleopole at $48.0^{\circ} \mathrm{N}, 95.9^{\circ} \mathrm{E}$} & 2.8 \\
\hline \multicolumn{5}{|c|}{ paleopole at $49.2^{\circ} \mathrm{N}, 97.3^{\circ} \mathrm{E}$} \\
\hline \multicolumn{5}{|c|}{$\begin{array}{l}\text { * Sites } 10,16 \text { and } 21 \text { revealed only unstable magnetizations } \\
\text { and have not been included in these means. } \\
\text { * } \text { Selective means, excluding all sites with three or fewer } \\
\text { samples. } \\
n / N \text { is the ratio of samples used in the statistical analysis } \\
\text { to the number of samples demagnetized. } \mathrm{R}=\text { reversed, } \\
\mathrm{N}=\text { normal. }\end{array}$} \\
\hline
\end{tabular}

Paleozoic metamorphic country rock. Mineral constituencies comprise euhedral to subhedral albite, microcline, soda-rich pyroxene and amphibole, and biotite, with accessory feldspathoids, apatite and magnetite. The Litchfield is the most weathered and most poorly exposed of all three, as it is situated in a topographic lowland; its natural remanent magnetization (NRM) is unstable dur- 
ing storage and demagnetization and the results have not been included in this paper.

The ages of the plutons are well-constrained by $\mathrm{K}$-Ar dating, with $228 \pm 5 \mathrm{Ma}$ reported for biotite in the Agamenticus, and $221 \pm 8 \mathrm{Ma}$ for amphibole in the Abbott (Foland and Faul, 1977). A whole-rock $\mathrm{Rb}-\mathrm{Sr}$ date of $222 \pm 3 \mathrm{Ma}$ (Hoefs, 1967) supports the $\mathrm{K}-\mathrm{Ar}$ date of the Agamenticus. This implies a Middle to Late Triassic age for these plutons, which are ascribed by McHone and Butler (1984) to intraplate magmatism correlated with uplift before the opening of the Atlantic Ocean.

Sampling was carried out in 1985 with a portable gasoline-powered drilling apparatus. Samples were oriented with a Brunton compass; the intensities of magnetization are sufficiently low that the orientations should not be perturbed by the magnetization of the rocks. Between 3 and 8 samples were collected from each site, with individual samples at least $2 \mathrm{~m}$ apart from each other. Sampling sites are indicated in Fig. 1 and the number of samples and sites is given in Table 1.

\section{Paleomagnetic results}

NRM intensities ranged from 0.02 to $10 \mathrm{~A} / \mathrm{m}$, as measured on a Schonstedt SSM-1A spinner or ScT cryogenic magnetometer housed in a magnetically shielded room with residual field less than $200 \mathrm{nT}$. Since most cores could be cut into at least two specimens, both thermal and alternating field (AF) demagnetization could be performed on the same samples, using Schonstedt equipment. Demagnetization results were plotted in orthogonal vector diagrams (Zijderveld, 1967) for visual inspection and directions for the components of magnetization have been calculated with the principal component analysis program of Kirschvink (1980). Determination of characteristic directions by this program used the demagnetization trajectories heading towards the origin, including the coordinate origin itself.

Figure 2 illustrates six representative demagnetization diagrams. The bulk of the samples revealed dominant northerly or northwesterly and steeply down directions with blocking temperatures up to $550^{\circ} \mathrm{C}$ (Fig. 2a,b), but in many cases the demagnetization trajectories bypass the origin to reveal a southerly and shallowly upward hightemperature or high-coercivity component of magnetization. The north(west)erly and down direction is interpreted as a Cretaccous or Cenozoic magnetic overprint. In a significant number of samples, however, the northerly and steeply down overprint was not very dominant (Fig. $2 c-f$ ); in these samples the southerly and shallow direction is well isolated and we call this the characteristic magnetization direction. Thermal and AF demagnetization of specimens from the same sample reveal identical results (Fig. 2c,f). The behavior of Abbott samples (Fig. 2b) was similar to that of the Agamenticus samples (Fig. 2a, c-f), although in three sites of the Agamenticus northerly and shallowly downward components were revealed (Fig. $2 \mathrm{~d}, \mathrm{e})$ that are antipodal to the southerly characteristic magnetizations.

The characteristic magnetizations display discrete blocking temperature intervals generally between $500^{\circ}$ and $580^{\circ} \mathrm{C}$, which is indicative of fine-grained magnetite, whereas coercivities revealed by AF demagnetization are in excess of 25 to $40 \mathrm{mT}$ (Fig. 2e, f). Acquisition of isothermal remanent magnetization (IRM) shows saturation below $0.3 \mathrm{~T}$, supporting the identification of magnetite as the principal magnetic carrier. Reflectedlight petrography shows ilmenite and magnetite grains, which have the appearance of primary igneous minerals. Scanning electron microscopy with energy-dispersive analysis shows that the magnetites are titanium-free, and that finely dispersed sub-micron grains of iron oxide (magnetite?) occur in felspars; the larger magnetites, up to 100 micron in size, do probably not contribute to the characteristic, high-blocking temperature, high-coercivity magnetization.

Normal and reversed-polarity samples were powdered to yield magnetic extracts which were analyzed with a Curie balance. Pure magnetite is indicated as the principal magnetic mineral, with Curie temperatures of $560-580^{\circ} \mathrm{C}$. During the thermomagnetic runs some magnetite appears to oxidize to hematite.

Sixteen sites in the two plutons revealed the characteristic directions, whereas three sites (10, $16,21)$ showed only present-day field or unstable 

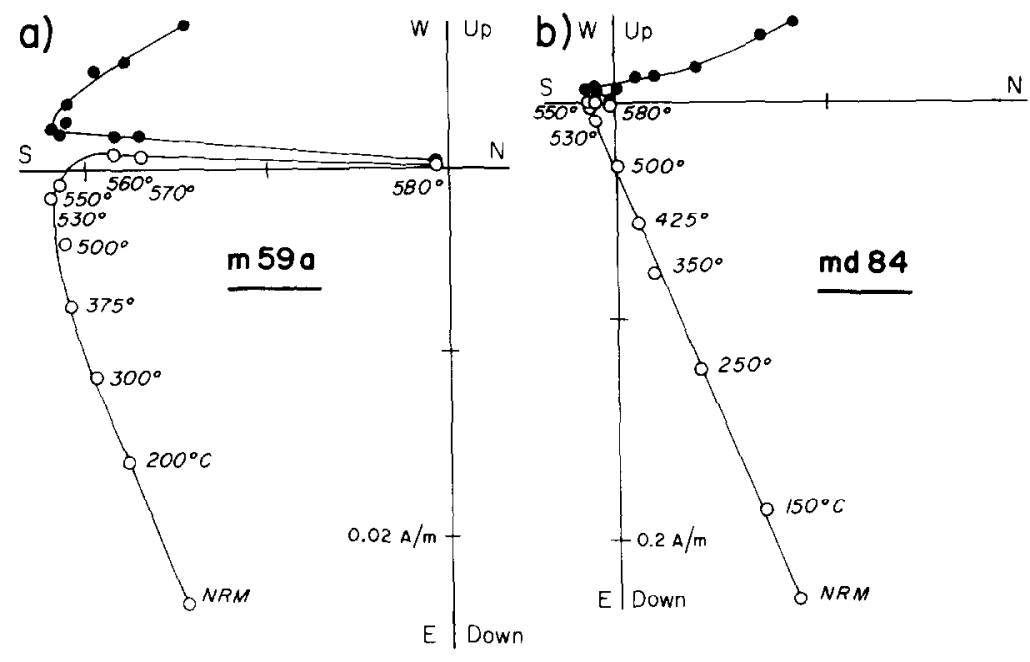

c)

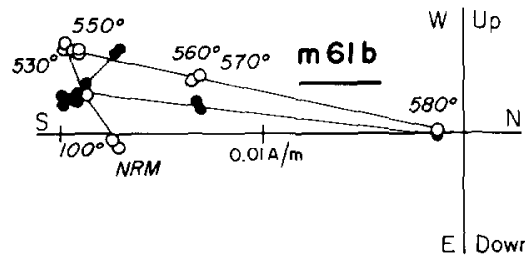

d)
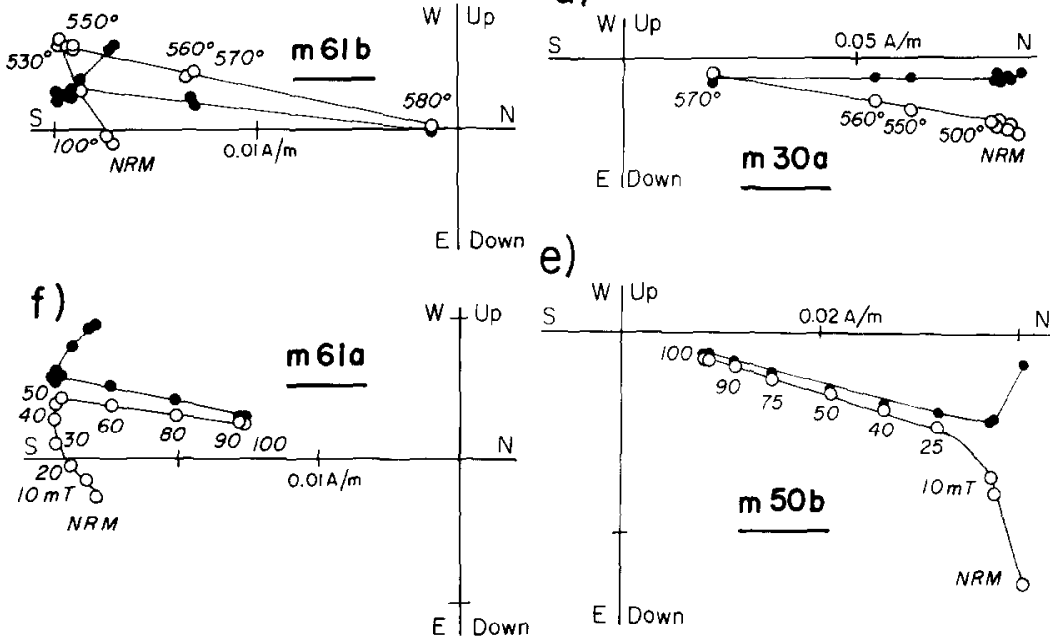

Fig. 2. Orthogonal vector diagrams of six representative specimens (md 84 is from Abbott, the others from Agamenticus), showing characteristic magnetizations (all) and lower blocking-temperature overprints (dominant in a and b). Plotted points represent projections of the magnetic vector after each demagnetization step onto the horizontal (full symbols) and $\mathrm{N}-\mathrm{S}$ vertical plane (open symbols). Intensities of magnetization are indicated along the axes, and temperatures $\left({ }^{\circ} \mathrm{C}\right)$ or AF fields (mT) are given for each demagnetization step. Diagrams $c$ and $f$ represent specimens from the same sample, treated with thermal and $A \Gamma$ techniques. Diagrams $d$ and $e$ show normal-polarity directions, opposite to the characteristic directions of the samples shown in a, b, $c$ and $f$.

magnetizations; these sites have not been included in Table 1. Some samples from each of the Abbott sites and from three of the Agamenticus sites were rejected. The directions from these samples were either completely aligned with the present-day field, or they showed only unstable magnetizations; Table 1 lists the ratios of samples used to the total number of samples analyzed. We note that the overall mean directions for the two plutons do not change appreciably, even if we ex- clude site-means based on three or fewer samples (Table 1: selective means).

Figure 3 illustrates the sample characteristic directions and the 16 site means for the Abbott and Agamenticus plutons (see also Table 1). It can be seen that the northerly and southerly characteristic directions of the Agamenticus are nicely antipodal; because thermomagnetic runs with a Curie balance show pure magnetite and similar behavior for normal and reversed polarity samples, a self- 


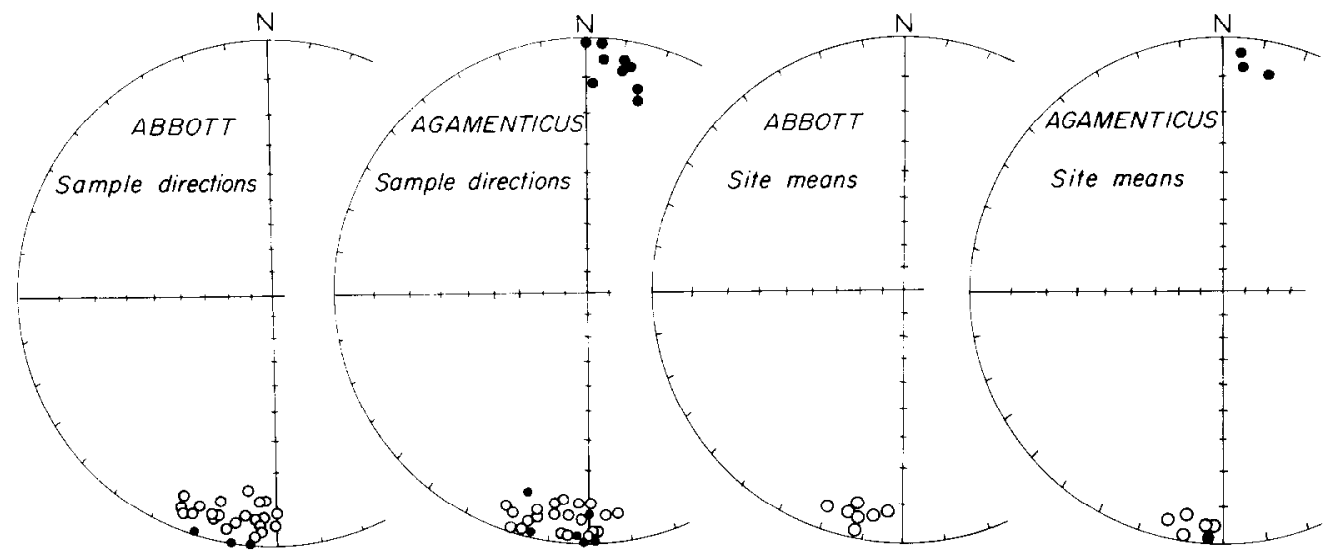

Fig. 3. Equal-angle projections of the characteristic directions of magnetization for samples and site means (see also Table 1). Full (open) symbols represent projections onto the lower (upper) hemisphere.

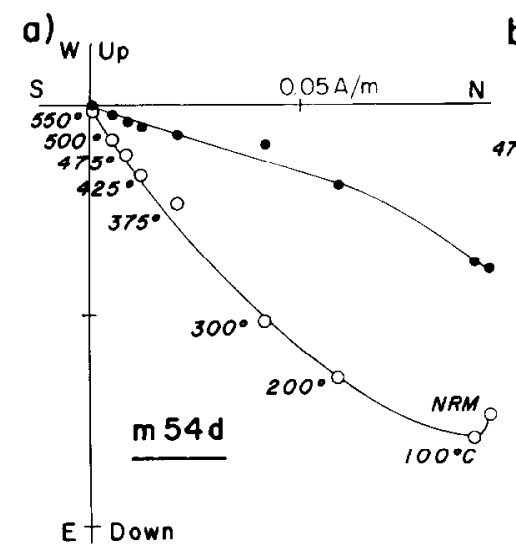

b)
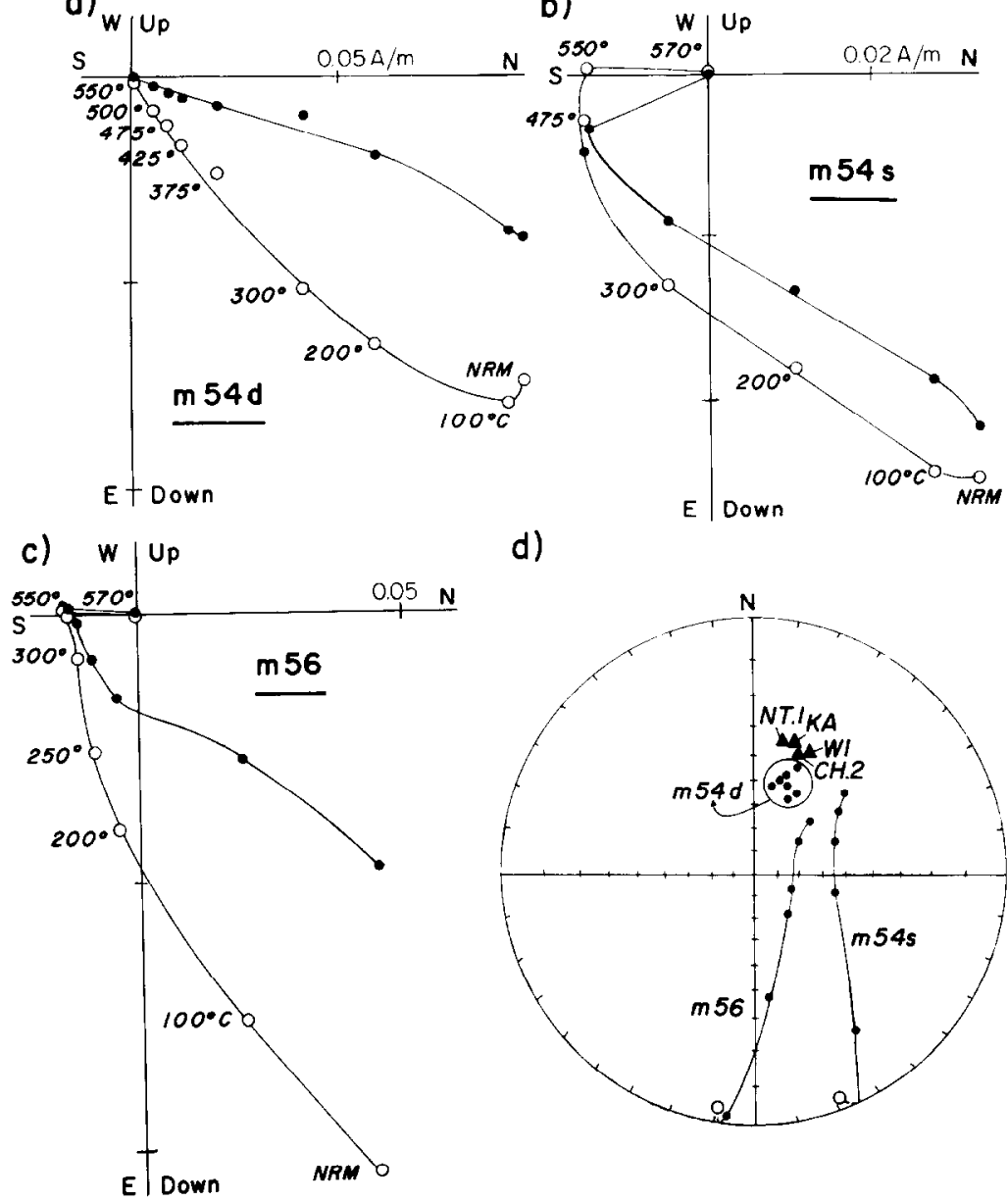

d)

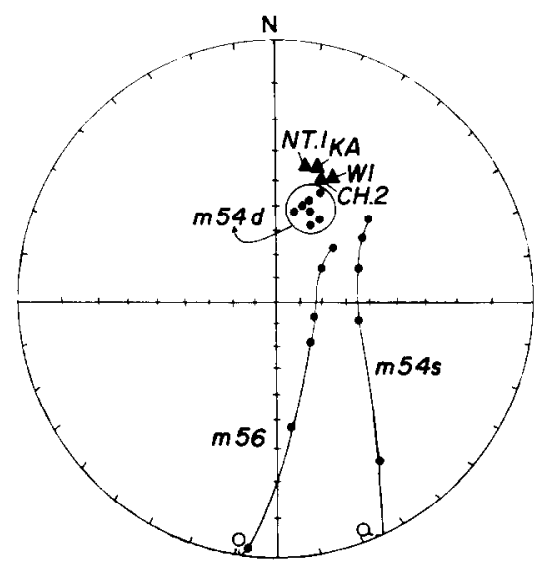

Fig. 4. Orthogonal vector diagrams (as in Fig. 2) for (a) a sample from a dike which intrudes at site 26 of the Agamenticus pluton and (b, c) for two specimens from the adjacent (baked) contact zone in the syenite of the pluton. Handsample 54 contained both diabase (d) and syenite (s). (d) Equal-angle projection (as in Fig. 3) of the directions from these three samples during demagnetization. For comparison, reference directions are shown from the Chinle (CH.2), Kayenta $(K A)$, and Wingate (WI) formations and the Newark Trend, Group 1 (NT. 1) as calculated from the paleopoles (see May and Butler, 1986) for a southern Maine location. 
reversal mechanism is an unlikely explanation for the antipodal directions. This implies that the plutons contain magnetizations acquired during a field reversal, and that their cooling took place over a period long enough for the field to reverse itself. The antipodal nature of the directions also guarantees that the mean direction of characteristic magnetization is not biased by later systematic overprints.

At site 26 in the Agamenticus pluton, a small basaltic dike of $3 \mathrm{~m}$ in thickness cuts the syenite. Paleomagnetic measurements and demagnetizations of the dike reveal a north-northeasterly direction with a downward inclination of about $30-40^{\circ}$ (Fig. 4a). This direction is close to the directions for southern Maine expected from latest Triassic-Early Jurassic paleomagnetic results as determined by studies of the Chinle (CH.2), Kayenta $(K A)$, and Wingate $(W I)$ formations and the Newark Trend (NT.I); these extrapolated directions are shown in Fig. 4d. This dike would thus likely be of the same age as similar dikes and flows associated elsewhere with the early opening of the Atlantic Ocean. The syenite contact rocks of the Agamenticus have been partially reset and show the north-northeasterly dike direction superimposed on higher blockingtemperature southerly characteristic directions (Fig. 4b, c). This contact test shows that the dike magnetization is younger than that of the syenite pluton; if our estimate of the dike age as latest Triassic-Early Jurassic is correct, then this confirms the primary or very early acquisition time of the plutons' magnetization.

\section{Discussion}

The mean directions for the Abboll and Agamenticus plutons are listed in Table 1 with the associated statistical parameters. Also listed are the means of the normal and reversed-polarity sites, which provide a positive reversal test (Fig. 5a). The contact test, the reliable and self-consistent age dates of the rocks, the reversal test, and the excellent statistical parameters of the site-mean distributions convince us that it is very likely that the mean directions are representative of the Middle to Late Triassic paleomagnetic field. However, before we can compare our new results with the APWP for cratonic North America, we need to establish that no subsequent tectonic tilting occurred or if it did, what the likely effects would be on our mean directions. By the time the Triassic plutons intruded in Maine, the main orogenic (Paleozoic) phases in New England had long terminated. However, the subsequent rifting of the early Atlantic Ocean along the eastern seaboard was usually accompanied by dike intrusion, continental margin uplift and grabenfilling sedimentation, the remains of which can be seen today in the Bay of Fundy area, the Connecticut graben and the Newark Basin, to name a few. The sedimentary rocks of these graben typically show minor tilts with strikes parallel to the rift axes, i.e., usually parallel to the coast. In southern Maine, no Triassic-Jurassic sedimentary rocks have been identified, but it appears likely, if a tilt occurred, that here too it would have been about a strike more or less parallel to the coast, i.e., tilts would

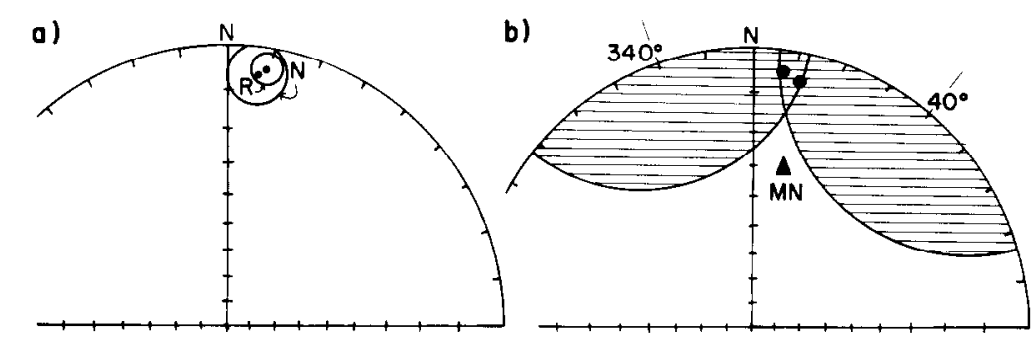

Fig. 5. a. Mean directions from the reversed and normal-polarity magnetizations, compared to each other after inversion of the former in a reversal test (see also Table 1). b. Plot showing the area (shaded) that contains all possible mean directions after a tilt correction about strikes ranging from $340^{\circ}$ to $40^{\circ}$. Also shown is the direction (MN) expected for the southern Maine location on the basis of the Manicouagan reference pole, which is approximately of the same age as the poles of this study. 
be towards the west-northwest or the east-southeast. Examining the effects of such hypothetical tilts on the mean directions, we can see the domains containing tilt-corrected directions in Fig. $5 \mathrm{~b}$, using a range of strikes varying between $340^{\circ}$ and $40^{\circ}$. Also shown in Fig. $5 \mathrm{~b}$ is the expected direction in southern Maine based on the Manicouagan pole ( $M N$, derived from pole at $59^{\circ} \mathrm{N}, 90^{\circ} \mathrm{E}$ ), and it can be seen that this direction is appreciably steeper than the ones we observe in the Abbott and Agamenticus. A dip in excess of $40^{\circ}$ is needed (using the two extreme strikes mentioned above) to bring the observed direction of the Maine rocks close to that of the Manicouagan reference direction; such a large tilt seems very unlikely. A tilt-correction about an implausible E-W strike would require a dip of about $20^{\circ}$. We conclude that an unrecognized structural tilt, as an explanation for the shallow inclination, is a remote possibility.

Pole positions for the Abbott and Agamenticus can be compared with the APWP of May and Butler (1986) in Fig. 6. The position of our two new poles (triangles) along the trend of the Triassic APWP segment is in good agreement with the ages along the track: both our poles fall near the point on the path where the Early Triassic ( $T r l$ ) changes into the Late Triassic (Tru). However, the new paleopoles from this study fall about $10^{\circ}$ farther away from North America than would be expected from previous results. This "far-sided" effect translates into an inclination, as observed, which is about $15-20^{\circ}$ too shallow, whereas the declination is seen to be in agreement with the position of the poles along the track. As discussed above, likely tilts would be about coast-parallel strikes which for moderate dips affect primarily the declination, but hardly the inclination (Fig. $5 b)$, so we argue that it is very unlikely that structural tilts are the cause of the small but significant deviation observed in pole location.

Our preliminary conclusion is that the Triassic segment of the North American APWP may have to be modified slightly to incorporate our new results, but additional new Triassic paleopoles from stratified rocks are needed to substantiate this suggestion. We note that a previously existing pole for the Middle to Late Triassic Ankareh

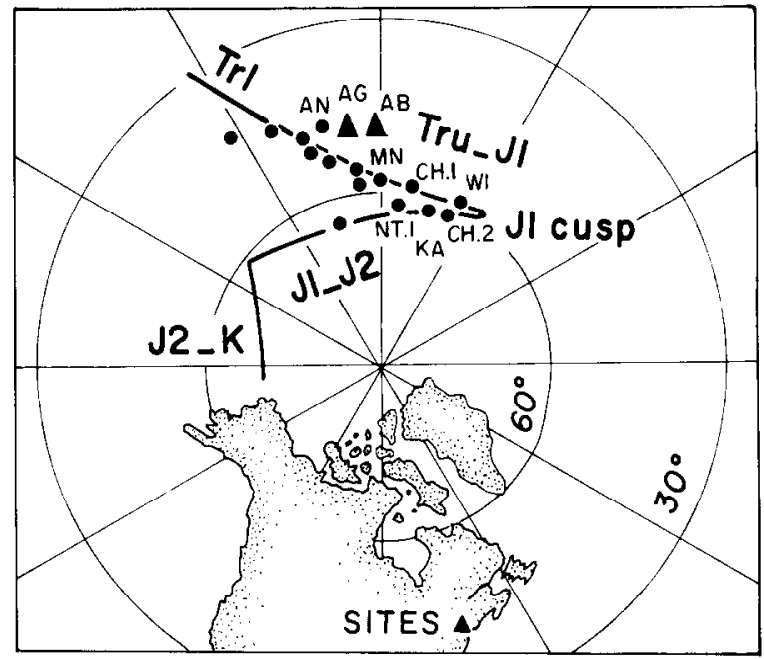

Fig. 6. A previously published apparent polar wander path (May and Butler, 1986) showing the Early Triassic $(T r l)$ to Late Triassic $(T r u)$, Early Jurassic $(J I-J 2)$ and Late Jurassic-Cretaceous $(J 2-K)$ tracks, which meet in the $J 1$ and $J 2$ cusps. Plotted points represent individual paleopoles (from Gordon et al., 1984 and May and Butler, 1986) with the poles from this study (triangles $A B, A G$ ) added. Poles $A N$ (Ankareh), $M N$ (Manicouagan), $C H$ (Chinle), $K A$ (Kayenta), $W I$ (Wingate) and Newark Trend, Group 1 (NT.I) are detailed in Gordon et al. (1984) or May and Butler (1986).

Formation of Wyoming ( $A N$ in Fig. 6) is likewise somewhat farther away from the craton than the small-circle polar wander track shown in Fig. 6. A modification of the APWP wander path would change the concept or the nature of the small-circle curve fitted to this path by Gordon et al. (1984). This technique assumes that the motion of a continent with respect to the pole is relatively constant for certain prolonged periods and that the APWP of that continent would constitute the inverted trace of the motion, not unlike a hot-spot trace (Morgan, 1972). Gordon and colleagues showed, with the then available data, that the Late Carboniferous to Early Jurassic APWP segment constitutes such a small-circle, which then allowed them to calculate a paleomagnetic Eulcr pole (PEP). The PEP, in turn, is the pivot about which the continent moved with respect to the pole. Subsequent to this Late Carboniferous-Early Jurassic track, a new direction of the North American continent is indicated by a Jurassic track. In Fig. 6 these tracks are shown after Gordon et al. (1984), with modifications by May 
and Butler (1986). The Jurassic $(J 1-J 2)$ track and the Late Triassic-Early Jurassic (Tru-J1) track meet in the $J I$ cusp, which is supported by some poles of Early Jurassic age. Our new results complicate the relatively simple Triassic path and future work is required to determine if the track of Gordon et al. necds to be modificd.

The other major implication of our new results is that displacements previously calculated for some Cordilleran terranes (Monger and Irving, 1980; Hillhouse and Grommé, 1984), on the basis of Triassic reference poles for the craton, may need to be re-evaluated. Our new results would indicate more southerly paleolatitudes for the craton, by about $10^{\circ}$, and the displacements would therefore be reduced by the same amount.

\section{Acknowledgments}

We thank A.M. Hussey, D.S. Barker, J.G. McHone, M.T. Swanson, J. Laird and D.W. Newberg for their advice on the field geology and sampling. This study was supported by the Division of Earth Sciences, the National Science Foundation, grants EAR 83-13085 and 84-07007.

\section{References}

Barker, D.S., 1965. Alkalic rocks at Litchfield, Maine. J. Petrol., 6: $1-27$.

Foland, K.A. and Faul, H., 1977. Ages of the White Mountain
intrusives-New Hampshire, Vermont and Maine. Am. J. Sci., 277: 888-904.

Gordon, R.G., Cox, A. and O'Hare, S., 1984. Paleomagnetic Euler poles and the apparent polar wander and absolute motion of North America since the Carboniferous. Tectonics, 3: 499-537.

Hillhouse, J.W. and Grommé, C.S., 1984. Northward displacement and accretion of Wrangellia: new paleomagnetic evidence from Alaska. J. Geophys. Res., 89: 4461-4474.

Hoefs, J., 1967. A Rb-Sr investigation in the southern York County area, Maine, in: Variations in isotopic abundance of strontium, calcium, and argon and related topics. MIT Press, Cambridge; Mass., 127-129.

Hussey, A.M., 1962. The geology of southern York County, Maine. Maine Geol. Surv., Spec. Rep., 4: 67 pp.

Irving, E. and Irving, G.A., 1982. Apparent polar wander paths, Carboniferous through Cenozoic, and the assembly of Gondwana. Geophys. Surv., 5: 141-188.

Kirschvink, J.L., 1980. The least-squares line and plane and the analysis of paleomagnetic data. Geophys. J. R. Astron. Soc., 62: 699-718.

May, S.R. and Butler, R.F., 1986. North American Jurassic apparent polar wander: implications for plate motion, paleogeography and Cordilleran tectonics. J. Geophys. Res., 91: 11519-11544.

McHone, J.G. and Butler, J.R., 1984. Mesozoic igneous provinces of New England and the opening of the North Atlantic Ocean, Geol. Soc. Am. Bull., 95: 757-765.

Monger, J.W.H. and Irving, E., 1980. Northward displacement of north-central British Columbia. Nature, 285: 289-294.

Morgan, W.J., 1972. Deep-mantle convection, plumes and plate motions. Am. Assoc. Pet. Geol. Bull., 56: 203-213.

Zijderveld, J.D.A., 1967. AC demagnetization of rocks: analysis of results. In: D.W. Collinson, K.M. Creer and S.K. Runcorn (Editors), Methods in Paleomagnetism. Elsevier, Amsterdam, pp. 254-287. 